\title{
Parliaments in Central and Eastern Europe: Changing Legislative Institutions*
}

\author{
PETR KOPECKÝ** \\ Department of Political Science, Leiden University
}

\begin{abstract}
Parliaments emerged as one of the key political institutions in the postcommunist transition. Endowed with the significant power they acquired under the old communist constitutions, they were assigned the task of drafting and ratifying the new democratic constitutions in the transition period. Like most other institutions in Central and Eastern Europe, parliaments have undergone important changes in terms of how they function and in relation to their external environment. This article provides an introductory overview of the changing nature of parliaments in the region, focusing on two important areas of legislative studies. The first part of the article looks at the role of parliaments in representation. The second part offers several generalisations about the relationship between parliaments and their respective executive branches. By reviewing these two aspects of legislative process, some insights are also provided into the changing internal workings and procedures of CEE parliaments.

Sociologický časopis/Czech Sociological Review, 2005, Vol. 41, No. 3: 361-373
\end{abstract}

\section{Introduction}

Modern democracies are unthinkable without parliaments. Parliament provides the institutional platform for the interaction of intermediary agencies: the parties, interest groups, or social movements that link them to society. Parliament also links society with other democratic institutions, the executive, judiciary or state bureaucracy. In that sense, parliament is the key structure of representation. In every political system the parliament encompasses a wide range of institutions, rules and procedures, and political organisations, and as such it can be viewed as the focal point around which revolve all the crucial questions of political style, legitimacy and democratic accountability. In addition, parliament is multifunctional: it legislates (hence the frequently used reference to 'the legislature'), i.e. it makes laws. However, it is also the place where political elites are trained and socialised, where diverse

\footnotetext{
* This article draws on an earlier chapter by the author on post-communist parliaments, published in White, Batt and Lewis [see Kopecký 2003]. The author would like to thank two anonymous reviewers of this journal for their comments.

* Direct all correspondence to: Petr Kopecký, Department of Political Science, Leiden University, Wassenaarseweg 52, 2333AK Leiden, the Netherlands, e-mail: kopecky@fsw.leidenuniv.nl
} 
social groups and nationalities of one state are integrated, where national administration is subjected to an oversight, and where the interests of society interests, and frequently even public policies, are articulated.

The parliaments in communist Eastern Europe existed more or less as rubberstamping bodies. Although no Eastern European communist regime abandoned its parliament, it was so subordinated to the Communist Party apparatus that particularly its legislative activities and oversight functions were minimal, at least until the 1980s, when communist leaderships throughout the region began to lose their grip on society [see Nelson and White 1982]. The wave of political change that swept across Eastern Europe in the early 1990s propelled parliaments almost overnight from institutions with very limited autonomy in decision-making into bodies that at least initially became one of the key political players in each country. There were at least two reasons for the pivotal role parliaments acquired. First, parliaments were handed the task of drafting and ratifying the new democratic constitutions. This presented them with an opportunity to cement a strong position for themselves within the emerging political system. Second, parliaments were endowed with significant powers from the start of the transition, as the previous communist constitutions had made parliaments powerful institutions (at least on paper), and it was these same constitutions that established the rules of the game under which the new parliaments began operating in the post-communist era.

However, like most other institutions in the region, parliaments have undergone numerous changes, both in their internal functioning and in relation to their external environment. They are clearly not the same institutions they were during and immediately after the uncertain and extraordinary period of transition to democracy (i.e. from 1989 to the mid-1990s). This article provides an introductory overview of the changing nature of parliaments in Central and Eastern Europe ${ }^{1}$ (CEE), focusing on two important areas of legislative studies. The first part of the article provides a look at the role of parliaments in representation, while the second part presents several generalisations concerning the relationship between parliament and the executive branch. By reviewing these two aspects of legislative process the final aim is to provide some insights into the changing internal workings and procedures of CEE parliaments. It should be noted that in this article the similarities between CEE parliaments are emphasised rather their differences. This of course does not mean that there are no differences. CEE parliaments have always differed in many institutional and behavioural aspects and will continue to do so. However, by placing emphasis on similarities, the aim is to highlight the increasing degree of convergence between CEE parliaments and the parliaments in established (Western European) democracies.

${ }^{1}$ Central and Eastern Europe refers here to all eight new EU member states among the postcommunist countries, plus the three Balkan EU-candidate states; e.g. Bulgaria, Romania and Croatia. It thus excludes Russia and most other former Soviet Republics, and several of the Balkan countries. 


\section{Parliaments and representation}

Parliaments are the symbols of representation, perhaps more so than anything else. Sometimes they are deliberately set up in such a way as to reflect a society's sociocultural diversity. The communist legislatures tried to ensure the equal representation of women, peasants, workers, and national minorities, etc., and created parliaments that were supposed to be more or less a mirror of their respective societies. In most contemporary European democracies, it is political parties that are the key agents of representation. Parties select and campaign on behalf of and provide lists of representatives, who when elected sit in parliament and, if in control of a majority, also form the government. This is a party government model of representation, in which voters simply delegate their power to the political parties that best represent their political preferences. However, links between parliaments and the electorate can also exist, especially in between the elections, through various forms of constituency representation, wherein individual MPs promote the interests of particular geographical areas, sectors of society, or even individual constituents.

These different models of representation are not mutually exclusive, and in most political systems they to a large extent co-exist [see Andeweg and Thomassen 2003]. There is usually a set of informal practices that determine which particular form of representation dominates, or what happens if conflicts between various forms of representation arise; for example, if an individual MP is caught between the interests of his or her constituents on the one hand and those of the government on the other. Patterns of representation also depend on a range of formal political institutions, most importantly the kind of electoral system and the nature of political parties and party systems. In this the CEE parliaments are no exception: the development of their links to the electorate has been greatly influenced by the nature of post-communist parties, elections and electoral systems. It has also been greatly affected by the particular structure of parliamentary membership.

\section{Parties and elections}

Organised political parties emerged relatively slowly in post-communist CEE. Owing in part to the strong anti-party sentiments among both the population and the new political leaders [see Lewis 2000] and in part to the particularly suppressive nature of the communist regimes, the early transition period was dominated by broadly based anti-communist movements and umbrella organisations, such as Civic Forum and the Public Against Violence in former Czechoslovakia, the National Salvation Front in Romania, Sajudis in Lithuania, and Demos in Slovenia. With a few exceptions, like Bulgaria, it was these movements that also won the first freely contested parliamentary elections.

Parties began to emerge only as these broad movements started to break up in parliament during their first term in office. In this sense, parliaments performed one very important function in the early stages of post-communist politics: they became 
the arenas in which new political alliances were forged and new political parties were established. Given that most of the newly established parties were formed from above and consequently lacked solid links with society on the whole, their survival would have been inconceivable without the institutional, logistical and often also financial support that was provided to them by parliaments.

However, the rapid and somewhat disorderly process of party formation had negative consequences for the links between parliament and the electorate. Many political parties disappeared during the first parliamentary term and other parties were formed instead. For example, in contrast to the initial eight parliamentary parties that were in the Federal Assembly in the former Czechoslovak Federal parliament in 1990, there were no fewer than sixteen parliamentary parties by the end of 1991. In Slovakia, eighteen parties and coalitions registered for the elections in 1994 but in fact represented 31 parties and movements. In addition, the composition of parliamentary parties (clubs) frequently changed: members either switched to another parliamentary group or became independent. In Slovakia, for example, 44 parliamentary seats (out of 150) shifted from one parliamentary party to another between the elections of 1990 and 1992; between the 1992 and 1994 elections 28 seats shifted from one party to another [Malová and Krause 2000]. The parties themselves often fractured into several sub-groupings, or disappeared altogether [Gillespie et al. 1995; Kask 1996].

The fragmentation of parties and the party system caused a good deal of confusion among voters and effectively prevented the formation of stable ties between the representatives and the represented. However, it also affected the internal functioning of parliaments because in the wake of such instability parliamentary party leaders had to struggle to impose the party line on parliamentary party members. Consequently, individual MPs introduced their own legislation, often against the wishes of their party or the government coalition they represented, more frequently than they tend to in the established parliaments of Western Europe.

The links between parliament and the electorate are also shaped by the electoral system. The system of proportional representation (PR) based on party lists combined with large constituencies generally favours representation by parties rather than the emergence of strong links between individual MPs and their constituencies. In contrast, the majority system with single-member districts, such as the British first-past-the post, is more favourable to the formation of such links. The countries of Central and Eastern Europe have various electoral systems, but most have adopted, for elections to the lower house, either a PR electoral system (e.g. Bulgaria, Croatia, Czech Republic) or a mixed electoral system, where a part of the house is elected on the basis of a PR system and a part in single-member constituencies (e.g. Hungary, Lithuania).

However, the key problem with electoral systems in the region has always been the relatively frequent changes they have experienced. Manipulation of the electoral system has been most visible in connection with establishing the legal thresholds for entering parliament [see Shevtsova 1999]. For example, Latvia, Lithuania, and Poland 
all raised these barriers during the 1990s in order to reduce the number of parties in parliament. The Czech Republic has done so for coalitions of parties. The result of these changes has been a reduction in the number of (parliamentary) parties, which is certainly a positive development given the scale of party fragmentation that existed in some countries, such as Poland. However, other effects of this electoral engineering are somewhat more questionable, for example, the large proportion of votes 'wasted' on the small parties that did not make it into parliament. Most importantly, frequent tinkering with the electoral rules, for instance changing the size of electoral districts, or making changes in how preferential votes count, has also made it difficult for MPs to form links between themselves and their local constituencies.

Nevertheless, certain patterns are now emerging across the region as parties and party systems have relatively stabilised and as the institutional framework of the new democracies has become more and more settled. Parliamentarians are now primarily anchored in their political parties, not least because MPs now owe their career to the party rather than to their own personal qualities and personalities. Voters also note vote primarily for a political party rather than a particular individual. Parties are therefore slowly emerging as the key agencies of representation, as they are in most countries in Western Europe. Although the various forms of constituency representation tend to be relatively underdeveloped in the region, research in this area also suggests that some form of territorial and sectoral representation is becoming part of MPs' working routines, for example, in Slovakia [Malová and Siváková 1996] and Poland [van der Meer Krok-Paszkowska 2000] and other countries that use the mixed electoral systems [see Birch 2001].

\section{Members}

Many of the deputies that were in the first post-communist parliaments in CEE came from the ranks of the opposition movements that existed in the region. In some parliaments these movements won a majority after the first free elections (e.g. Czechoslovakia, Poland), in other parliaments it was the (ex-)communist parties that dominated (e.g. Bulgaria). The opposition movements themselves were largely composed of intellectual elites, independent professionals and artists, who had constituted the backbone of anti-communist dissent. As a result, the early parliaments, especially those in which the opposition was victorious, managed to acquire legitimacy in the eyes of the population, as former dissidents replaced the communistera deputies and apparatchiks. In some cases, like in the former Czechoslovakia, the replacement process actually occurred before the first democratic elections, as a result of agreements between the outgoing communist regime and the opposition during round table negotiations after the Velvet Revolution. The Federal Assembly and the Czech and Slovak National Councils purged themselves, and between one-third and one-half of the MPs in the federal and national councils were replaced by candidates supported by the anti-communist opposition. 
However, the gains in terms of democratic legitimacy were offset by the inexperience of these new members in operating in a large organisation. Moreover, former dissidents were elected alongside a sizeable group of prominent actors and musicians, and their presence lent the electoral lists of newly formed and largely unknown parties extra visibility and popularity. Although dissidents and artists often displayed convincing rhetorical skill in parliamentary debates, they nonetheless had poor organisational skills, and the loyalty they had to organisations like parliamentary parties or parliamentary committees was weak. Ironically, it was the MPs of the (ex-)communist parties that often turned out to be the more effective parliamentarians, as they had already learned the necessary skills of negotiation, deal-making and constituency representation under the previous regime.

Consequently, the composition of the first democratic parliaments partly contributed to the comparatively high turnover of MPs that has occurred since then. Each successive parliament in the region has been largely comprised of different MPs, which undermines the ability of MPs over the long term to specialise in specific areas or issues and hinders legislative continuity and stability. Many of the former dissidents and the majority of artists did not view their position as MPs in terms of a life-long career, and they consequently did not even seek re-election. Moreover, the organisational instability of political parties and the relatively high level of electoral volatility has meant that incumbency rates among the CEE parliamentarians have remained relatively low, though perhaps not as low as in the early years of post-communist transformation.

For the most part there are no quotas pertaining to the representation of particular sectors of society in the new parliaments of the region. There are, however, several exceptions, as Poland, Hungary and Romania have introduced measures aimed at either guaranteeing or encouraging the representation of their ethnic minority groups [see Juberías 1998]. In comparison with the communist period the representation of women has suffered, but the number of female MPs in parliament is not uniformly low throughout all the CEE countries when compared to the European average. In June 2002, in the countries of Europe, including the Scandinavian states, the average percentage of women in both houses of parliament was $16.7 \%$ (see www.ipu.org). In the CEE countries, also in June 2002, this figure was exceeded significantly by Bulgaria (26.25\%), Poland (21.62\%) and Croatia (20.53\%), and matched by both Latvia (17\%) and Estonia (17.82\%). However, both Hungary $(9.07 \%)$ and Lithuania (10.64\%) were well below the European average.

In CEE countries generally the position of MP is acquiring the attributes of political professionalism. The shift towards professional MPs and politicians has been furthered by significant increases in the salaries of MPs, the introduction of travel and accommodation allowances, and by a general improvement in their working conditions, for instance, with the creation of new parliamentary buildings. Croatia is a good example of dramatic developments, as the position of MP was given professional full-time status, accompanied by a full salary, in 1992, shortly before the elections to the second post-communist parliament. Until then, MPs had only been entitled to per diem payments and other small reimbursements of costs. These 
changes mean that being an MP is now a lucrative job, which makes parliamentarians more dependent on their party organisations and also less likely to defect from the party or even to vote against it. In addition, professionalism empowers parliamentarians in the region to perform their representative duties on a more consistent and solid basis. It improves the conditions for serving both the sectarian interests of various social, religious, professional and sectoral organisations, and the territorial interests of an MP's constituency.

Finally, the institutional context in which individual MPs operate has been consolidated and is now fixed. It is more difficult now for an MP to leave a party and/or to set up a completely new party. In Hungary, for example, the number of MPs required to form a parliamentary party and thus also to receive a financial subsidy and other administrative support from the parliamentary budget was raised from ten to fifteen in recent years [Ilonszki 2000]. Similar measures have been introduced in the Czech Republic, where parliamentary parties newly formed during the legislative term do not moreover receive any financial subsidy from the parliamentary budget [Kopecký 2001]. In the Polish Sejm - the parliament perhaps most notorious for party fragmentation - the minimum number of MPs required to form a parliamentary party $(k l u b)$ has also been increased, from the initial three to fifteen. It was in Poland also that during the second legislative term several MPs from every parliamentary party but one were expelled for breaking with voting discipline [van der Meer Krok-Paszkowska 2000]. Indeed, expulsions of MPs have occurred in all countries in the region, and this indicates that parliamentary parties and their leaderships have obtained at least some leverage to control the behaviour of their members. The picture of flux and instability that dominated in most accounts of the first democratic parliaments in the region [e.g. Remington 1994; Ágh 1994; Longley and Zajc 1998] has now given way to accounts that stress the emergence of distinct parliamentary cultures, settled institutional structures and established parliamentary routines.

\section{Executive-legislative relations}

As in the relationship between parliament and the electorate, formal rules largely shape the development of executive-legislative relations. Interestingly, the dominant model of executive-legislative relations in the CEE region is the parliamentary system of government with a weak formal president (head of state) and a government that is dependent on legislative confidence. This development is opposite that in most Latin American countries and many of the post-Soviet republics. Indeed, in the CEE context Romania is an exception as a country with a semi-presidential system of government, in which the head of state possesses significant powers vis-à-vis both the government and parliament. Several other countries in the region, like Poland and Croatia, also initially adopted a semi-presidential system, modelled on the French Fifth Republic, but eventually introduced constitutional reforms (Poland in 1997 and Croatia in 2000) to create a parliamentary system of government. 
It can generally be claimed that CEE parliaments enjoyed significant advantages over their respective governments in the early years of transition. This made legislatures appear stronger and more powerful in the matrix of executive-legislative relations than the legislatures of the established parliamentary democracies of Western Europe were. First, the parties that formed governing coalitions in the region were seldom able to achieve or impose party loyalty among their MPs. In addition, owing to strong political polarisation, coalition partners often quarrelled with each other, sometimes to such an extent that part of the government voted with the opposition in parliament. In some countries, such as the Czech Republic (to 1996) or Hungary, this did not lead to any significant governmental instability, but perhaps only because the parties in the opposition suffered even more from splits and flux than the parties in the government. However, in countries like Estonia, Latvia, and Poland, during the first post-communist decade the governments lasted on average less than one year, a figure well below the European average of 1.9 years [Blondel and Müller-Rommel 2001].

Second, the frequent domestic conflicts between the governments (prime ministers) and presidents in the CEE countries undermined executive cohesion. The highly charged relationship between the former Polish president Lech Walesa and several of the Polish governments between 1990 and 1995 is a good example [see van der Meer Krok-Paskowska 2000]. Arguably, these conflicts sent the Polish political elite back to the drawing board to alter the 'Little Constitution' so as to substantially curb the powers of the president. Disagreements over political issues, personnel questions and executive powers were also behind the destabilising conflicts that existed between, respectively, presidents and prime ministers Zhelev and Dimitrov in Bulgaria, Illiescu and Roman in Romania, and Göncz and Antall in Hungary during the first half of the 1990s [e.g. Baylis 1996]. The conflict between the former president Kováč and the former prime minister Mečiar in Slovakia between 1994 and 1998 led not only to changes in the constitutional framework, but even resulted in the government being implicated in the kidnapping of president's son [Kopecký 2001]. Parliaments of course benefited most from these conflicts, because in the absence of cohesive executive leadership they were less vulnerable to demands to cede powers to either presidents or governments.

Third, largely as a result of the communist legacy, the executive was not in a position to exercise effective authority in the political system [Goetz and Wollmann 2001]. The communist regimes established or often just extended the tradition of having a strong executive, with power concentrated in the hands of a small ruling elite. However, they also created (or continued) a system of government that comprised a massive network of bureaucracies, agencies and planning bureaus. Under communism, the chief task of the central bodies of government was to implement and administer policies that had been decided elsewhere. As a result, the post-communist executive was institutionally fragmented. The structures of central government had been subordinate to the parallel Communist Party apparatus under the previous regime and they were therefore poorly equipped to take the lead in government deci- 
sion-making in the new regimes. In addition, state administrative personnel, heavily politicised by the previous regime, were not capable of providing the executive with sufficient support to draft and implement policies. Unfortunately, the administrative resources that parliaments as a whole and the individual MPs in particular had to draw on were no larger or better than those of the executive [Olson 1997].

This means not only that the governments or presidents were initially unable to create and maintain the executive dominance that is typical for the established democracies of Western Europe, but also that the overall quality of legislation has been poor, as is evident from the frequent amendments and changes to existing laws that characterises the legislative process in the region. The quality of the legislation was of course also not helped by the fact parliaments in the region were initially confronted with an enormous amount of legislation that they were required to process within a short period of time.

The civil service in CEE countries is still considerably politicised [GrzymalaBusse 2003]. Nevertheless, the position of governments has generally improved throughout the region, to the extent where the balance of power between the executive and the legislature increasingly favours the former. Several elements have been involved in this shift. First, as mentioned above, parties and party systems are much more stable than they were in the early years of transition. This has enabled political leaders to better organise the relationship between the executive and legislative branches and to impose some party discipline and cohesion [Ágh 1995; Malová and Siváková 1996]. The internal organisation of parliament has therefore also become gradually more stable, especially given the fact that parliamentary party clubs themselves dominate the party as a whole. Political party leadership often consists of a large group of members of the parliament, which means that conflicts between the parliamentary party faction and the external party are often less visible or less existent than in many established democracies.

The second key element in the changing balance of power between executives and legislative assemblies in the region has been the formation of the core executive, centred on the head of government. Reform of central government and state administration has been carried out to varying degrees in almost all the countries of the region. Its refashioning has enabled the executive to extend and consolidate its position around powerful institutions, most notably the council of ministers and the minister of finance [Goetz and Wollman 2001]. These changes at the executive level have certainly not led to the disempowerment of legislatures, which continue to wield at least some oversight authority over the executive branch. However, the institutional resources that are now at the disposal of the executives tend to outweigh the resources of the legislatures.

Finally, the balance of power between the executives and the legislative assemblies has been greatly affected by the processes of European integration. Most countries in the CEE region sought speedy accession to the EU. Eight post-communist countries joined in May 2004, while others, most notably Romania, Bulgaria and Croatia, are likely to join in or shortly after 2007. Preparing for accession to the EU 
is, politically and administratively, a very lengthy and complicated process, which requires candidate states to comply with a host of conditions specified by the European Commission (the so-called Copenhagen criteria of 1993). EU membership is conditional on the adoption of the body of EU laws contained in the acquis communautaire.

This process had a significant impact on governance in CEE countries in general and on the reform of central administration in particular [Grabbe 2001]. For example, the EU demanded that candidate states implement reform to create a politically neutral civil service capable of both effectively transposing the acquis communautaire and providing efficient support for a democratically elected government [e.g. Verheijen 1999]. It is of course still too early to assess how well these reforms, now in effect in all the new EU member states, succeeded in achieving their objectives, particularly that of empowering the core executive. However, it is interesting to note, for example, that pressures to meet the demands from the EU has already led to the professionalisation of central administration in key policy areas, and this in turn has created 'islands of excellence' within the civil service [Goetz 2001].

The position of the executive in the region has moreover been significantly strengthened vis-à-vis the parliaments by the introduction of fast-track legislative procedures. This relates again to the transposition of the acquis communautaire and its 9000 items of legislation. It would be inconceivable for such a vast number of laws to be adopted through normal legislative procedures, especially those inherited from the communist past. The CEE countries that sought or are still seeking EU membership had to amend their rules of procedure (i.e. standing orders) and treat (some) EU-related laws as a legislative priority (Bulgaria), or even call extraordinary parliamentary sessions to speed up the process (Slovenia). In addition, the management of EU accession was itself highly centralised and it concentrated all responsibilities in the hands of the governments [Lippert, Umbach and Wessels 2001]. Taken together, it is not surprising that these procedures and processes privileged the executive branch and consequently reduced the independent policy-making capacity of parliaments.

\section{Conclusion}

The first post-communist parliaments experienced numerous problems that typically affect institutions in transition societies. They initially had to function under a provisional or highly disputed constitutional framework. They were constrained in their actions by their own as yet unsettled internal procedures, by the presence of inexperienced MPs, and by the fragmentary character of parliamentary parties at the time. They were also under significantly less external control from established political parties and powerful interest groups and less influenced by strong executives, as these institutions were still underdeveloped or in the process of transition. The bulk of scholarship on the first post-communist parliaments reflected this tran- 
sitory state of affairs in research predominantly on the role of parliaments in the transition to democracy, in the peaceful resolution of conflicts, and in establishing the norms and procedures of new democracy [Remington 1994; Olson and Norton 1996; Ágh and Ilonszki 1996].

The contemporary parliaments in Central and Eastern Europe are different. Their internal structures and procedures are more defined and settled. Legislative tasks are performed in an increasingly routine process. The system of parliamentary committees is in place. Large groups of MPs have by now served for one or more parliamentary terms, which together with the generally improved conditions for MPs' work have contributed to stability and continuity in the legislative process. Parliamentary parties have also become more accepted as the means whereby parliament and individual MPs organise the legislature's operations. It is partly as a result of these political developments that legislative studies on contemporary CEE parliaments have come to resemble studies on parliaments in already established democracies [Olson and Crowther 2002]. Indeed, this special issue of the Czech Sociological Review, focusing on a classic topic of legislative research, is a poignant reminder of how far legislative scholarship on the region has already become integrated in the mainstream of parliamentary research.

PETR KOPECKÝ is a researcher at the Netherlands Organisation for Scientific Research (NWO) based at the University of Leiden. His major research interests are democratisation, political parties and civil society. He is currently working on a comparative research project concerning the relationship between political parties and the state in new democracies. His books include Parliaments in the Czech and Slovak Republics: Party Competition and Parliamentary Institutionalization (Ashgate 2001), and Uncivil Society? Contentious Politics in Eastern Europe (Routledge 2003).

\section{References}

Ágh, Attila. (ed.) 1994. The Emergence of East Central European Parliaments: The First Steps. Budapest: Hungarian Centre of Demoracy Studies Foundation.

Ágh, Attila 1995. "The Experience of the First Democratic Parliaments in East Central Europe". Communist and Post-Communist Studies 28 (2): 203-214.

Ágh, Attila and Gabriela Ilonszki. (eds.) 1996. Parliaments and Organized Interests: The Second Steps. Budapest: Hungarian Centre of Demoracy Studies Foundation.

Andeweg, Rudy B. and Jacques Thomassen. 2003. "Between Electorate and Executive:

Parliament as a Linchpin." Paper presented the workshop on Delegation in

Contemporary Democracies (March 22-April 2, 2003), ECPR Joint Sessions of Workshops, Edinburgh.

Baylis, Thomas A. 1996. "Presidents versus Prime Ministers. Shaping Executive Authority in Eastern Europe". World Politics 28 (3): 297-323. 
Birch, Sarah 2001. "Electoral Systems and Party Systems East and West." Perspectives on European Politics and Society 2 (3): 355-377.

Blondel, Jean and Ferdinand Müller-Rommel. (eds.) 2001. Cabinets in Eastern Europe. Houndmills: Palgrave.

Gillespie, Richard, Lourdes Lopez Nieto and Michael Waller. (eds.) 1995. "Factional Politics and Democratization." Special issue of Democratization 2 (1).

Goetz, Klaus H. 2001. "Making Sense of Post-communist Central Administration: Modernization, Europeanization or Latinization?" Journal of European Public Policy 8 (6): 1032-1051.

Goetz, Klaus H. and Hellmut Wollmann. 2001. "Governmentalizing Central Executives in Post-communist Europe: A Four-country Comparison." Journal of European Public Policy 8 (6): 864-887.

Grabbe, Heather. 2001. "How Does Europeanization Affect CEE Governance? Conditionality, Diffusion, and Diversity." Journal of European Public Policy 8 (6): 1013-1031.

Grzymala-Busse, Anna. 2003. "Political Competition and the Politicization of the State in East Central Europe." Comparative Political Studies 36: 1123-1147.

Ilonszki, Gabriella 2000. "Parties and Parliamentary Party Groups in the Making: Hungary, 1989-1997." Pp. 214-230 in Parliamentary Party Groups in European Democracies: Political Parties Behind Closed Doors, edited by Knut Heidar and Ruud Koole. London: Routledge.

Juberías, Carlos Flores. 1998. “Electoral Legislation and Ethnic Minorities in Eastern Europe: For or Against?" Pp. 297-318 in The New Democratic Parliaments: The First Years, edited by Lawrence D. Longley and Drago Zajc. Appleton: Research Committee of Legislative Specialists, IPSA.

Kask, Peet 1996. "Institutional Development of the Parliament in Estonia." The Journal of Legislative Studies 2 (1): 193-212.

Kopecký, Petr 2001. Parliaments in the Czech and Slovak Republics: Party Competition and Parliamentary Institutionalization. Aldershot: Ashgate.

Kopecký, Petr 2003. "Structures of Representation: New Parliaments of Central and Eastern Europe." Pp. 133-152 in Developments in Central and East European Politics, edited by Stephen White, Judy Batt and Paul G. Lewis. Basingstoke: Palgrave.

Lewis, Paul. G. 2000. Political Parties in Post-Communist Eastern Europe. London: Routledge.

Lippert, Barbara, Gaby Umbach and Wolfgang Wessels. 2001. “Europeanization of CEE Executives: EU Membership Negotitations as a Shaping Power." Journal of European Public Policy 8 (6): 980-1012.

Longley, Lawrence D. and Drago Zajc. (eds.) 1998. The New Democratic Parliaments: The First Years. Appleton: Research Committee of Legislative Specialists, IPSA.

Malová, Darina and Danica Siváková. 1996. "The National Council of the Slovak Republic: Between Democratic Transition and National State-Building." The Journal of Legislative Studies 2 (1): 108-132.

Malová, Darina and Kevin Krause. 2000. "Parliamentary Party Groups in Slovakia." Pp. 195-213 in Parliamentary Party Groups in European Democracies: Political Parties Behind Closed Doors, edited by Knut Heidar and Ruud Koole. London: Routledge.

Nelson, Daniel and Stephen White. (eds.) 1982. Communist Legislatures in Comparative Perspective. London: MacMillan.

Olson, David M. and Philip Norton. (eds.) 1996. The New Parliaments of Central and Eastern Europe. London: Frank Cass.

Olson, David M. 1997. "Paradoxes of Institutional Development: The New Democratic Parliaments of Central Europe.” International Political Science Review 18 (4): 401-416. 
Olson, David M. and William E. Crowther. (eds.) 2002. Committees in Post-Communist Democratic Parliaments. Comparative Institutionalization. Columbus: Ohio State University Press.

Remington, Thomas. (ed.) 1994. Parliaments in Transition. Boulder: Westview Press.

Shvetsova, Olga. 1999. "A Survey of Post-communist Electoral Institutions: 1990-1998." Electoral Studies 18 (3): 397-409.

van der Meer Krok-Paszkowska, Ania. 2000. Shaping the Democratic Order. The Institutionalisation of Parliament in Poland. Leuven: Garant.

Verheijen, Tony. (ed.) 1999. Civil Service Systems in Central and Eastern Europe. Cheltenham: Edward Elgar. 